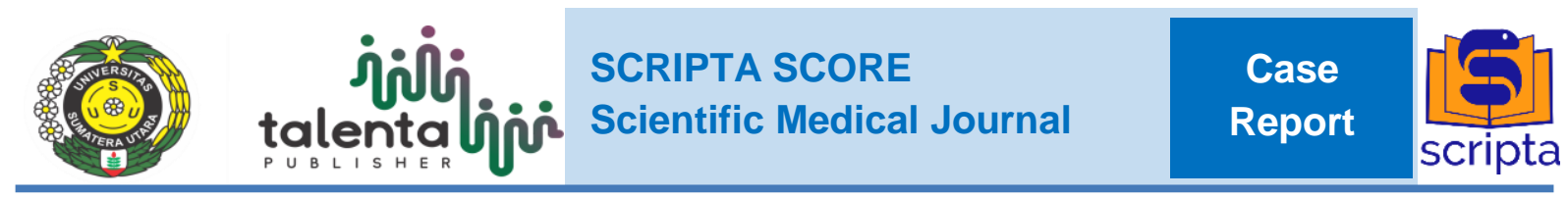

\title{
Newly Diagnosed Primary Immune Thrombocytopenia in Children: Which Guideline to Adhere?
}

\author{
Cipta Mahendra* \\ Department of Chemistry-Biochemistry, Faculty of Medicine and Health Science, Atma Jaya Catholic \\ University of Indonesia \\ *Correspondence: ciptamahendra@yahoo.com
}

\begin{abstract}
Background: Immune thrombocytopenia purpura (ITP) is an autoimmune disorder of bleeding which is defined as having thrombocytopenia (platelet count below 100.000/ $\mu \mathrm{L}$ ). Most ITP cases in children are acute and recent various guidelines have established a wait-and-see protocol as management for children with ITP since it is assumed to be temporary and will most likely to resolve spontaneously. Objectives: For this case report, a case of primary ITP in a child will be discussed. In the following discussion section, several ITP consensus guidelines will be discerned and compared to see which is the more appropriate guideline to adhere in managing a newly diagnosed ITP case in children. The case report is used as a 'trigger' to dissect the core treatment suggestions described in the inspected consensus guidelines. Case Illustration: A 6-years-old female child presents to a hospital with a chief complaint of having red spots in her arms and legs since a day ago. The red spots she complained was the first time to be experienced. She had no prior fever, (bloody) diarrhea, nausea, and vomiting. Physical examination showed no remarkable abnormalities other than numerous petechiae in the upper and lower extremities. Discussion: The patient in this case was finally admitted and treated in the hospital as an inpatient with corticosteroid, antibiotics, and platelet concentrates despite the current guidelines that generally advocate against these treatments. This case report may give an insight regarding the factors needed to be considered before treating a child with newly diagnosed ITP. Conclusion: The Joint Working Group (JWG) consensus seems to be the most comprehensive guideline in treatment of newly diagnosed ITP in children, compared to the American Society of Hematology (ASH) and International Consensus Report guideline.
\end{abstract}

Keywords: hematology, ITP, newly diagnosed, primary, thrombocytopenia

\section{ABSTRAK}

Latar Belakang: Immune trombositopenia purpura (ITP) merupakan sebuah penyakit perdarahan otoimun yang didefinisikan sebagai adanya trombositopenia (trombosit dibawah 100.000/ $\mu$ L). Mayoritas kasus ITP pada anak bersifat akut dan konsensus terkini menyarankan protokol "wait and see" sebagai tatalaksana untuk anak dengan ITP karena dianggap hanya sementara dan cenderung akan membaik secara spontan. Tujuan: Untuk laporan kasus ini, sebuah kasus ITP primer pada anak akan dibahas. Pada bagian diskusi, beberapa panduan terkait ITP akan diulas dan diperbandingkan untuk melihat panduan mana yang paling sesuai untuk mengatasi kasus baru (newly diagnosed) ITP pada anak. Laporan kasus ini digunakan sebagai pengantar untuk membahas intisari tatalaksana ITP dalam konsensus-konsensus yang dipakai. Ilustrasi Kasus: Anak perempuan berusia 6 tahun datang ke rumah sakit dengan keluhan utama adanya bintik-bintik merah pada kedua lengan dan tungkainya sejak sehari lalu. Bintik-bintik merah tersebut baru pertama kali dialami. Dia tidak menderita demam, diare (berdarah), nausea, dan vomitus. Pada pemeriksaan fisik, hanya ditemukan petekiepetekie di kedua ekstremitas atas dan bawah. Pembahasan: Pasien dalam kasus ini dirawatinapkan dan diberi kortikosteroid, antibiotik, dan konsentrat trombosit sebagai tatalaksananya, meskipun panduan-panduan yang ada secara umum tidak menyarankan tatalaksana demikian. Laporan kasus 
ini diharapkan memberikan wawasan terkait faktor-faktor yang penting untuk dipertimbangkan sebelum merawat seorang anak dengan kasus baru ITP. Kesimpulan: Konsensus Joint Working Group (JWG) tampaknya menjadi panduan paling komprehensif dalam tatalaksana anak dengan kasus baru ITP, dibanding panduan American Society of Hematology (ASH) dan International Consensus Report.

Kata Kunci: hematologi, ITP, newly diagnosed, primer, trombositopenia

Received [6 Sep 2020] | Revised [30 Apr 2021] | Accepted [20 Aug 2021]

\section{INTRODUCTION}

Immune thrombocytopenia purpura (ITP) is an autoimmune disorder of bleeding which is defined as having thrombocytopenia (platelet count below $100.000 / \mu \mathrm{L}) .{ }^{[1]}$ In addition, ITP is also not associated with any other systemic illness. ${ }^{[2]}$ Three main mechanisms of the platelet's deficiency are decreased production, immune-mediated destruction, and/or increased splenic phagocytosis of platelets. ${ }^{[3]}$ Clinical manifestations include petechiae, purpura, and/or ecchymosis, which usually appear in upper and lower extremities. $^{[2]}$ The mucocutaneous bleeding symptoms can also occur, i.e., gums, hard palate, or nasal septum, which often lead to nose and/or gum bleedings. ${ }^{[1,2]}$ According to the new classification after 2009 , the diagnosis of ITP can be classified into three types, i.e., newly diagnosed ( $<3$ months), persistent (3-12 months), and chronic (>12 months). ${ }^{[1]}$

In about $80 \%$ of ITP cases, the underlying cause(s) are usually not found, i.e., primary ITP; the other $20 \%$ of cases present the ITP as a manifestation secondary to coexisting disease(s). ${ }^{[3]}$ In these secondary ITP, the etiologies often include infections, malignancies, and some immunodeficiency and autoimmune diseases. ${ }^{[4]}$ Most ITP cases in children are of acute origin and are preceded by a viral illness. ${ }^{[4,5]}$ Recent various guidelines have established a wait-and-see protocol as management for children with ITP since it is assumed to be temporary and will most likely to resolve spontaneously. ${ }^{[6-8]}$ For this case report, a case of primary ITP in a child will be discussed, with the emphasis of considerations for medication treatment.

\section{CASE ILLUSTRATION}

A female child, 6 years old, presents to a hospital with a chief complaint of having red spots in her arms and legs since a day ago. She had no prior fever, (bloody) diarrhea, nausea, and vomiting. A nose bleeding was confessed by the patient but no gum bleeding. She felt just a slight decrease in appetites. History of allergy was denied. She reported no history of hospitalization. The red spots she complained was the first time to be experienced.

On physical examination, the patient was stable. No abnormalities in vital signs were found. She was fully aware (Glasgow Coma Scale $=15$ ) and had a good nutrition status. All the examinations were normal except for the upper and lower extremities, where numerous petechiae were found. No bruises were discovered. The nostrils were clean with no blood when checked. The gum and mouth were within normal findings.

The patient was then diagnosed with suspected dengue hemorrhagic fever (DHF), with differential diagnosis of ITP. Ringer lactate (RL) infusion of 1.000 $\mathrm{mL} / 24 \mathrm{~h}$, routine hematology (hemoglobin, hematocrit, leucocyte, thrombocyte), blood glucose, and blood type testing were initially conducted. Upon completion, the laboratory results gave normal results except for thrombocyte level of just $4.000 / \mu \mathrm{L}$. The patient was then consulted to a pediatrician. The specialist decided to order complete hematology testing (routine hematology, red blood cell 
indices, Westergren erythrocyte sedimentation rate/ESR, red blood cell distribution width/RDW, leucocyte differential count) and peripheral blood smear examination for further checkups. The diagnosis was changed into ITP and the patient was treated with cefotaxime, prednisone, and thrombocyte concentrate infusions. The patient was transferred to a high care unit for strict observations due to extremely low platelet level in her blood. The drugs were given shortly without waiting for complete hematology testing results first. The medications (cefotaxime and prednisone) were to be given daily, 3 times a day at an appropriate dosage. The thrombocyte concentrate was also to be infused for 3 units a day for 2 days.

The requested peripheral blood smear testing was done before the treatment commenced. The examination gave abnormal results for thrombocyte, i.e., lowered estimated amount and existence of giant thrombocytes. No platelet clumping was reported. The erythrocytes were described to be hypochromic microcytic, polychromatic, and mild-moderate anisocytosis. The leucocytes were otherwise normal. Meanwhile, the complete hematology testing was undertaken after the first day of treatment. An improved number for thrombocyte level was observed at $12.000 / \mu \mathrm{L}$. All other parameters were still within normal limits.

Another blood testing was conducted after the second day of treatment. Further improvement of thrombocyte level was seen at $91.000 / \mu \mathrm{L}$. In response to the result, no additional thrombocyte infusions were given and the patient was kept monitored for another one day (third day) to make sure the progress is in the right track. The cefotaxime and prednisone were still continually administered.

The next day (fourth day), the patient was discharged from hospital at noon without any symptom. Some petechiae were still found at the arms and legs but had been reduced significantly in numbers. There was no blood testing at the day before the discharge. The patient was given methylprednisolone tablet as takehome medicine, taken 3 times a day for 3 days. After 3 days passed, the patient was returning to hospital to visit a pediatrician office at the outpatient clinic to monitor further progress of improvement. At this time, the blood testing was requested as final confirmation to see whether the thrombocyte had returned to normal level. A thrombocyte level of $520.000 / \mu \mathrm{L}$ was yielded. All other parameters were again within normal limits. The petechiae were no longer seen at the moment. The patient was then given additional methylprednisolone tablets for the next 4 days as a tapering-off medication.

\section{DISCUSSION}

This patient was initially diagnosed with DHF due to the presenting appearance of petechiae in the patient, as well as the endemicity of such disease in the region. However, the ITP was made as differential because the patient was not reporting any fever prior to the petechiae's emergence. After the discovery of isolated thrombocytopenia in this patient through first blood testing, the final diagnosis was changed to ITP and the dengue serology was not checked because there was no fever complained by the patient and there was no any hematocrit increase, warranting the exclusion of DHF as diagnosis. Although the erythrocytes morphology was reported to be abnormal in the peripheral blood smear examination, the hemoglobin level and red blood cell indices values in this patient remain normal. Based on the newest classification of ITP diagnosis, this patient is suitable to be classified as newly diagnosed ITP (from diagnosis until 3 months). On the case of this patient, the appearance of petechiae without bruises corresponds to a grade 1 (minor) or 2 (mild) ITP, according to the newest 2019 International Consensus Report on ITP (see Table 1). ${ }^{[7]}$ 
Table 1. Bleeding Scale for Pediatric Patients with $\operatorname{ITP}^{[7]}$

\begin{tabular}{ll}
\hline Grade & Bleeding \\
\hline Grade 1 (minor) & $\begin{array}{l}\text { Minor bleeding, few petechiae ( } \leq 100 \text { total) and/or } \leq 5 \text { small bruises }(\leq 3 \mathrm{~cm} \text { in } \\
\text { diameter), no mucosal bleeding }\end{array}$ \\
Grade 2 (mild) & $\begin{array}{l}\text { Mild bleeding, many petechiae ( }>100 \text { total) and/or }>5 \text { large bruises }(>3 \mathrm{~cm} \text { in } \\
\text { diameter), no mucosal bleeding }\end{array}$ \\
Grade 3 (moderate) & $\begin{array}{l}\text { Moderate bleeding, overt mucosal bleeding, troublesome lifestyle } \\
\text { Severe bleeding, mucosal bleeding leading to decrease in } \mathrm{Hb}>2 \mathrm{~g} / \mathrm{dL} \text { or } \\
\text { suspected internal haemorrhage }\end{array}$ \\
\hline
\end{tabular}

The most recent American Society of Hematology (ASH) 2019 consensus guideline has suggested that children with newly diagnosed ITP who have no or minor bleeding should be observed only without the need to be given any therapy even for corticosteroid - regardless of platelet counts. ${ }^{[6]}$ No additional remark or consideration was described. This is quite in contrast to the guideline issued by the joint working group (JWG) of some European hematology associations (Germany, Austria, Switzerland) in $2018^{[8]}$ and the 2019 International Consensus Report on ITP,${ }^{[7]}$ which offer more flexible approaches to manage ITP children without or with only mild bleeding symptom. Both guidelines are fundamentally in accordance with the ASH consensus, i.e., treatments are usually not necessarily needed for newly diagnosed ITP in children without or with only mild bleeding, even when the platelets are extremely low $(<20-30.000 / \mu \mathrm{L})$. However, the JWG consensus also emphasizes the need to consider other factors in deciding whether to start treatment or observation alone, especially the social factors. The consequences for school activities, patient's preference, medication and (psycho)social background, and access to healthcare facilities are among factors that need to be considered when deciding the suitable management for newly diagnosed ITP children without or with only mild bleeding. Although the guideline acknowledges the very low platelet level status $(<20-30.000 / \mu \mathrm{L})$ as an indicator for risk of severe hemorrhage, it also states that a treatment decision based only on platelet count without looking at individual patient's circumstances is no longer a standard algorithm. Should the medication therapy be decided to be given to the patient, the JWG supports the corticosteroid as first-line therapy to be given. The offer for such treatment is especially if the patient is afraid of bleeding and the wavering to give medication will hardly be acceptable. ${ }^{[8]}$

Similar considerations are also described in the 2019 International Consensus Report on ITP. Most children with newly diagnosed ITP do not require any therapy because the platelet level will often restore to normal within few days. ${ }^{[7]}$ The consensus also encourages hospitalization only for children with grade 3 or 4 bleeding. Nonetheless, several cases may warrant the hospitalization and treatment be appropriate to be administered: risk of intracranial bleeding, anxious or worried parents due to the disease, far distance from the hospital. ${ }^{[7]}$

There is scarcity of recent clinical trial comparing the efficacy of corticosteroid treatment versus observation alone. A study by Blanchette et al. in 1993 supported the use of prednisone as initial therapy in children with acute and severe ITP. ${ }^{[9]}$ Similar suggestion was also put forward by Carcao et al. in their 1998 study. ${ }^{[10]}$ Prednisone was deemed safe, inexpensive, and effective to increase platelet level after a week. However, a study countering the Blanchette and Carcao's study finding for prednisone therapy was published by Buchanan and Holtkamp in their 1984 study of the same drug therapy for children with newly 
diagnosed ITP. ${ }^{[11]}$ They reported no significant differences between the children treated with prednisone and placebo. Supporting the Buchanan and Holtkamp's study, was the study by Dickerhoff and von Ruecker in 2000. They conducted a retrospective clinical trial study and concluded that most studied children were not given any therapy for their ITP, even when platelet count was $<10.000 / \mu \mathrm{L}^{[12]}$ These conflicting studies may be the background reason of the 2019 ASH consensus suggesting against the use of corticosteroid therapy. The ASH consensus panelists have determined that the possible harms of corticosteroid use even for short course - outweigh the unclear, controversial benefit perceived.

On the case of the patient in this case report, although she had only petechiae without any bruise, the occurrence of platelet level $<10.000 / \mu \mathrm{L}$ in blood testing result made the decision to treat with a corticosteroid justifiable to reduce the possibility of more severe bleeding that may happen if not assisted with the prednisone medication. Another consideration was the age of the patient when diagnosed and her parent's effort to visit the hospital 'only' for some red spots on the patient's arms and legs without any fever. At 6 years old, the child will be expected to be highly active which puts her as high risk for possible bleeding caused by daily activities. Further, the visit to hospital should be interpreted that her parent is already in concern with the unusual, petechiae symptom acquired in the child. The 2018 JWG guideline or 2019 International Consensus Report seems to be the most suitable consensus to adhere when managing newly diagnosed ITP children without or with mild bleeding. These guidelines give thorough considerations before deciding to treat the patients by judging not only from the bleeding grade or platelet count level but also from the individual patient's circumstances.
Regarding the use of antibiotics, the JWG consensus states that such use as infection prophylaxis is usually not needed. In this case report, the patient was given cefotaxime as prophylactic antibiotic. The patient's hospital almost always has many other patients to admit with various kinds of diseases, putting the hospital vulnerable to be populated with many infectious organisms. Although the ITP itself is not a bacterial-caused disease, the antibiotic was still administered to reduce the risk to contract any iatrogenic disease. There was no statement about the use of antibiotics recommendation in the $\mathrm{ASH}$ and International Consensus Report guideline.

The use of thrombocyte concentrate infusion has been described in the JWG and International Consensus Report guideline. No such infusion is described as a treatment regime in the ASH guideline. Both JWG and the International Consensus Report guideline state the thrombocyte concentrate infusion to be used only in emergency situation. The International Consensus Report guideline suggests to use the infusion in case of organ- or lifethreatening bleeding to increase the platelet level as immediately as possible. A more specific suggestion is seen on the JWG consensus, recommending the platelet infusion to be given to patients with severe, World Health Organization (WHO) grade III/IV bleeding (see Table 2). In this case report, although no major bleeding was occurring in the patient, the thrombocyte infusion was given with the same reason as the rationale of the prednisone therapy, i.e., to reduce the likelihood of more severe bleeding resulted from such an extremely low platelet count. Fortunately, no adverse reaction was seen in the patient during the infusion therapy.

The infusion initiation was in accordance to Squire's review article, which recommends to start thrombocyte transfusion when the level falls below $10.000 / \mu \mathrm{L}$ for nonbleeding 
thrombocytopenic patients without complicating comorbidities (fever, prior infection, being treated with drugs known to damage the platelets). ${ }^{[13]}$ Similar with the JWG and International Consensus Report, Squire also emphasizes the infusion therapy to be individualized and adjusted to the current clinical situations faced.

Taken together, compared to the ASH and the International Consensus Report guideline, the JWG consensus is likely to be more comprehensive and specific guideline to consider when dealing with newly diagnosed ITP cases in children due to its extensive details in every treatment aspect for the disease, especially for the patient's preference and circumstances.

\section{CONCLUSION}

The decision to treat a newly diagnosed children with ITP should be based not only on platelet count or bleeding grades, but also the individual patient's circumstances. Reviewing the most current guidelines about the management of newly diagnosed ITP in children, the 2018 consensus published by the JWG or 2019 International Consensus Report seems to give a more relevant and comprehensive recommendations to consider in deciding the treatment regime compared to the 2019 ASH guideline. Incorporation of remarks to address individual patient's circumstances in the treatment decision and the thrombocyte infusion should be written in the next, revised ASH guideline to make this guideline more appropriate and practical to be

Table 2. Bleeding scales according to the WHO. ${ }^{[8]}$

\begin{tabular}{|c|c|}
\hline Bleeding grade & Definition \\
\hline 0 & No signs of bleeding \\
\hline I & $\begin{array}{l}\text { Petechiae } \\
\text { Small hematomas, ecchymoses }(<10 \mathrm{~cm}) \\
\text { Bleeding from mucous membranes (mouth, nose) } \\
\text { Epistaxis ( }<1 \text { h duration, no medical intervention necessary) } \\
\text { Subconjunctival hemorrhages } \\
\text { Vaginal bleeding (independent of menstruation, no more than } 2 \text { bandages/day } \\
\text { necessary) }\end{array}$ \\
\hline $\begin{array}{l}\text { II } \\
\text { (no transfusion } \\
\text { required) }\end{array}$ & $\begin{array}{l}\text { Hematomas, ecchymoses }(>10 \mathrm{~cm}) \\
\text { Epistaxis ( }>1 \text { h duration or tamponade necessary) } \\
\text { Retinal bleeding without visual impairment } \\
\text { Vaginal bleeding (independent of menstruation, more than } 2 \text { bandages/day } \\
\text { necessary) } \\
\text { Melena, hematemesis, hemoptysis, hematuria, hematochezia } \\
\text { Bleeding from puncture sites } \\
\text { Bleeding in muscles and joints }\end{array}$ \\
\hline $\begin{array}{l}\text { III } \\
\text { (transfusion } \\
\text { required) }\end{array}$ & $\begin{array}{l}\text { Epistaxis } \\
\text { Bleeding from mucous membranes (mouth, nose) } \\
\text { Vaginal bleeding } \\
\text { Melena, hematemesis, hemoptysis, hematuria, hematochezia } \\
\text { Bleeding from puncture sites } \\
\text { Bleeding in muscles and joints }\end{array}$ \\
\hline $\begin{array}{l}\text { IV } \\
\text { (life threatening, } \\
\text { potentially } \\
\text { permanent } \\
\text { functional } \\
\text { impairment) }\end{array}$ & $\begin{array}{l}\text { Retinal hemorrhage with visual impairment } \\
\text { CNS bleeding } \\
\text { Hemorrhages in other organs with functional impairment (joints, muscles, } \\
\text { kidneys, lungs, etc.) } \\
\text { Fatal bleeding }\end{array}$ \\
\hline
\end{tabular}




\section{Compliance with Ethical Standards}

The author did not receive any means of funding for this article. No conflict of interest to declare in the preparation and making of this article. The contents of this review are solely of the author's opinion and do not reflect the thoughts of the author's department, faculty, or university. The patient's consent was taken from her parents (the patient's age was deemed incapable to provide an independent consent) and have given permission to be used at the case for this report.

Funding (optional): no funding received Conflict of Interest: nothing to declare Ethical approval: NA Informed consent: obtained from the patient's parents.

\section{REFERENCES}

[1] Provan D, Newland AC. Current management of primary immune thrombocytopenia. Adv Ther. 2015;32:875-87.

[2] Zainal A, Salama A, Alweis R. Immune thrombocytopenia purpura. J Community Hosp Intern Med Perspect. 2019;9(1):59-61.

[3] Samson M, Fraser W, Lebowitz D. Treatments for primary immune thrombocytopenia: a review. Cureus. 2019;11(10):e5849.

[4] Vaillant AAJ, Gupta N. Thrombocytopenic purpura immune [Internet]. Treasure Island: StatPearl Publishing; [updated 2019 Dec 1; cited 2020 Apr 20]. Available from: https://www.ncbi.nlm.nih.gov/books /NBK537240/

[5] Kessler CM, Latif H, Cunningham JM. Immune thrombocytopenia (ITP) [Internet]. USA: Medscape; [updated 2020 Jan 11; cited 2020 Apr 20]. Available from: https://emedicine.medscape.com/arti cle/202158-overview

[6] Neunert C, Terrell DR, Arnold DM, Buchanan G, Cines DB, Cooper N, et al. American Society of Hematology 2019 guidelines for immune thrombocytopenia. Blood Adv. 2019;3(23):3829-66.

[7] Provan D, Arnold DM, Bussel JB, Chong BH, Cooper N, Gernsheimer $\mathrm{T}$, et al. updated international consensus report on the investigation and management of primary immune thrombocytopenia. Blood Adv. 2019;3(22):3780-817.

[8] Matzdorff A, Meyer O, Ostermann H, Kiefel V, Eberl W, Kühne T, et al. Immune thrombocytopenia current diagnostics and therapy: recommendations of a Joint Working Group of DGHO, ÖGHO, SGH, GPOH, and DGTI. Oncol Res Treat. 2018;41(suppl 5):1-30.

[9] Blanchette VS, Luke B, Andrew M, Nielsen SS, Barnard D, de Veber B, et al. A prospective, randomized trial of high-dose intravenous immune globulin $\mathrm{G}$ therapy, oral prednisone therapy, and no therapy in childhood acute immune thrombocytopenic purpura. J Pediatr. 1993;123(6):98995.

[10] Carcao MD, Zipursky A, Butchart S, Leaker M, Blanchette VS. Shortcourse oral prednisone therapy in children presenting with acute immune thrombocytopenic purpura (ITP). Acta Paediatr Suppl. 1998;424:71-4.

[11] Buchanan GR, Holtkamp CA. Prednisone therapy for children with newly diagnosed idiopathic thrombocytopenic purpura. A randomized clinical trial. Am J Pediatr Hematol Oncol. 1984;6(4):355-61.

[12] Dickerhoff R, von Ruecker A. The clinical course of immune thrombocytopenic purpura in children who did not receive intravenous immunoglobulins or sustained prednisone treatment. J Pediatr. 2000;137(5):629-32.

[13] Squires JE. Indications for platelet 
transfusion in patients with

thrombocytopenia. Blood Transfus.

2015;13:221-6. 